\title{
PENGARUH PEMBERIAN ASI EKSKLUSIF TERHADAP TUMBUH KEMBANG BAYI UMUR 6-24 BULAN DI NAGARI SARIAK LAWEH KEC. AKABILURU
}

\author{
Hendra Mukhlis \\ Sekolah Tinggi Ilmu Kesehatan Perintis Padang \\ Jalan Adinegoro KM 17 Simpang Kalumpang Padang, Sumatera Barat \\ Email:hendramukhlis@yahoo.com
}

\begin{abstract}
Infant growth is largely determined by the amount of breast milk obtained including the energy and other nutrients contained in breast milk. Breastfeeding in Indonesia has decreased, especially in West Sumatra based on Indonesia Health Profile in 2014. This study aims to determine the Influence of Exclusive Breastfeeding on the growth and development of infants aged 6-24 months in Nagari Sariak Laweh Working Area Batu Hampar Puskesmas, District Akabiluru. The measured growth consists of body weight, body length and Head Circumference. Progress was seen through KPSP (Pre-Growth Questionnaire Developments). This type of research is an observational research that is analytic with Cross-Sectional research design. Data analysis used was univariate and bivariate (Independent T test). The study period was from October 2017-February 2018. The population in the study were infants aged 6-24 months in Nagari Sariak Laweh. The sample in this study amounted to 30 babies. Data collection was done by using questionnaire and direct measurement. The statistical results show that there is no Influence of Exclusive Breastfeeding on Infant Growth (body weight, body length, head circumference) and no Influence of Exclusive Breast Feeding on Infant Development (based on KPSP questionnaire).
\end{abstract}

Keywords: 6-24 month old infants, Exclusive ASI, Nagari Sariak Laweh, Batuhampar Health Center, Akabiluru District.

\section{PENDAHULUAN}

Usia dini terjadi peningkatan pertumbuhan dan perkembangan yang sangat pesat yaitu dari 0-5 tahun. Masa ini sering disebut fase " Golden Age " , sehingga sangat penting untuk memperhatikan tumbuh kembang anak agar terdeteksi sedini mungkin apabila terjadi kelainan. Tumbuh kembang mencakup 2 peristiwa yaitu pertumbuhan dan perkembangan yang sifatnya berbeda namun saling berkaitan dan sulit dipisahkan (Soetjiningsih, 2012). Pertumbuhan dan perkembangan bayi sebagian besar ditentukan oleh jumlah ASI yang diperoleh termasuk energi dan zat gizi lainnya yang terkandung di dalam ASI tersebut. ASI tanpa bahan makanan lain dapat mencukupi kebutuhan pertumbuhan sampai usia sekitar empat bulan. Setelah itu ASI hanya berfungsi sebagai sumber protein, vitamin dan mineral utama untuk bayi yang mendapat makanan tambahan yang tertumpu pada beras (Depkes RI, 2006).

Berdasarkan Profil Kesehatan Indonesia tahun 2014, cakupan pemberian,ASI Eksklusif pada bayi 0-6 bulan di Sumatera Barat adalah $73,6 \%$. Hal ini dapat mempengaruhi tumbuh kembang bayi berdasarkan ASI Eksklusif. Perlu ditingkatkan lagi, karena target nasional dalam pemberian ASI Eksklusif adalah 80\%. Di Indonesia, Provinsi yang sudah mencapai target yaitu Provinsi Nusa Tenggara Barat, dengan pencapaian $84,7 \%$. Perawatan kesehatan yang rutin untuk dilakukan setiap bulan yaitu 
posyandu. Perawatan kesehatan anak merupakan salah satu bentuk pola asuh yang dilakukan oleh orangatua untuk memelihara kesehatan anak agar dapat tumbuh dan berkembang dengan baik.

Dengan aktif dalam kegiatan posyandu ibu balita dapat memantau tumbuh kembang balitanya (Depkes RI, 2006). Gizi menjadi pengaruh yang paling dominan dalam pertumbuhan anak sampai umur 12 bulan. Makanan pertama, utama dan terbaik bagi bayi yang bersifat alamiah yaitu Air Susu Ibu (ASI). ASI mengandung semua gizi penting yang diperlukan oleh bayi untuk tumbuh kembangnya. Energi dan nutrisi yang dibutuhkan selama 6 bulan seluruhnya terkandung dalam ASI, sehingga pedoman Internasional menganjurkan pemberian ASI Eksklusif selama 6 bulan pertama. Hal ini didasarkan pada bukti ilmiah tentang manfaat ASI bagi daya tahan tubuh bayi, pertumbuhan dan perkembangan. Bayi yang tidak diberi ASI secara Eksklusif mempunyai resiko lebih banyak terkena penyakit. Menunda pemberian makanan padat dan memperpanjang pemberian ASI Ekskusif kepada bayi dapat mengurangi insiden terjadinya alergi makanan.

Selain ASI, tumbuh kembang bayi dipengaruhi oleh asupan nutrisi. MP-ASI merupakan makanan pendamping Air Susu Ibu yang dibutuhkan oleh bayi setelah mendapatkan ASI Eksklusif. Nutrisi untuk bayi, harus mengandung kaya energi, protein, dan mikronutrien (terutama zat besi, azink, kalsium, vitamin $\mathrm{A}$, vitamin $\mathrm{C}$, dan folat) yang dapat mempengaruhi panjang badan dan berat badan bayi. Di Kabupaten Lima Puluh Kota pada tahun 2014 pemberian ASI eksklusif sebesar 67,46\% meningkat dari tahun 2013 sekitar $66,45 \%$, angka ini sudah lebih tinggi dari data Riskesdas 2010. Riskesdas 2013 memberikan data bahwa $56,1 \%$ bayi baru lahir telah mendapat inisiasi menyusu dini dari ibunya. Di Puskesmas yang berada di Kabupaten Lima Puluh Kota, cakupan pemberian ASI Eksklusif paling tinggi yaitu di Nagari Situjuah $(86,49 \%)$, dan di Puskesmas Batu Hampar (72,54\%) dengan jumlah bayi 130 orang. Tujuan dari penelitian ini adalah untuk mengetahui apakah ada pengaruh pemberian ASI Ekslusif terhadap tumbuh kembang pada bayi umur 6-24 bulan di Nagari Sariak Laweh wilayah kerja Puskesmas Batu Hampar, Kecamatan Akabiluru tahun 2018.

\section{METODE PENELITIAN}

Desain, Tempat, Waktu, Populasi dan Sampel

Penelitian ini adalah penelitian Observasional yang bersifat analitik yaitu pengamatan pada Pengaruh Pemberian ASI Eksklusif terhadap tumbuh kembang pada bayi umur 6-24 bulan di Nagari Sariak Laweh wilayah kerja Puskesmas Batu Hampar, Kecamatan Akabiluru tahun 2018. Desain penelitian menggunakan desain cross sectional karena pada penelitian ini variabel independen dan variabel dependen akan diamati pada periode yang sama. Penelitian dilaksanakan di Nagari Sariak Laweh, Kecamatan Akabiluru Kabupaten Lima Puluh Kota dari bulan Oktober 2017 sampai Februari 2018. Populasi pada penelitian ini adalah bayi berumur 6-24 bulan yang berjumlah 130 orang di Nagari Sariak Laweh, Kecamatan Akabiluru, Kabupaten Lima Puluh Kota (Posyandu, 2017). Sampel pada penelitian ini adalah bayi berumur 6-24 bulan yang berjumlah 30 orang di Nagari Sariak Laweh, Kecamatan Akabiluru, Kabupaten Lima Puluh Kota. Pada penelitian ini dalam menentukan jumlah sampel, peneliti menggunakan semua sampel yang ada atau jumlah populasi yang digunakan dalam penelitian dengan menggunakan rumus.

Cara Pengambilan Subjek

Cara pengambilan sampel disetiap rumah menggunakan Purposive Sampling dimana teknik ini merupakan metode yang digunakan jika penetapan sampel didasarkan pada kriteriakriteria tertentu yang tujuannya adalah agar informasi yang didapatkan maksimal. Teknik ini digunakan di Nagari Sariak Laweh dengan mendapatkan responden bayi dengan ASI Eksklusif. Jenis data yang dikumpulkan adalah data primer dan data sekunder.

Data primer 
Data primer adalah data tumbuh kembang bayi, pengetahuan ibu dan sikap ibu dalam pemberian ASI Eksklusif.

Data sekunder

Data sekunder merupakan data yang didapat dari pihak kedua yaitu dari Posyandu dan Puskesmas di Nagari Sariak Laweh tahun 2017-2018.

\section{Metode Pengumpulan Data}

Teknik pengumpulan data yang digunakan dalam penelitian kualitatif adalah teknik yang memungkinkan diperoleh data detail dengan waktu yang relatif lama. Pada penelitian ini menggunakan metode wawancara dan dokumentasi .

\section{a. Wawancara}

Menurut (Sugiyono, 2011), Pengertian wawancara sebagai berikut: Wawancara digunakan sebagai teknik pengumpulan data apabila peneliti akan melaksanakan studi pendahuluan untuk menemukan permasalahan yang harus diteliti, dan juga peneliti ingin mengetahui hal-hal dari responden yang lebih mendalam dan jumlah respondennya sedikit/kecil.

\section{Dokumentasi}

Menurut (Sugiyono, 2011), dokumentasi bisa berbentuk tulisan, gambar atau karya-karya monumental dari seseorang. Dokumentasi merupakan pengumpulan data oleh peneliti dengan cara mengumpulkan dokumen-dokumen dari sumber terpercaya yang mengetahui tentang narasumber.

\section{Insrumen Pengumpulan Data}

Menurut (Sanjaya, 2011), Instrumen penelitian adalah alat yang dapat digunakan untuk mengumpulkan data atau informasi penelitian. Instrumen pengumpulan data yang digunakan adalah kuisioner, KMS, dan KPSP. Kuisioner

Kuesioner merupakan daftar pertanyaan yang akan digunakan oleh periset untuk memperoleh data dari sumbernya secara langsung melalui proses komunikasi atau dengan mengajukan pertanyaan

KMS (Kartu Menuju Sehat)

KMS adalah suatu alat atau tempat mencatat berat badan anak dibawah 5 tahun (balita) setiap kali ditimbang bulan secara teratur. Berat badan ini dibubuhkan pada KMS dalam bentuk sebuah titik

KPSP ( Kuisioner Pra Skrining Perkembangan)

KPSP adalah kuesioner yang berisi 9-10 pertanyaan tentang kemampuan perkembangan yang telah dicapai anak dengan sasaran anak umur 0-72 bulan (Depkes RI, 2006). Tujuan skrining atau pemeriksaan perkembangan anak menggunakan KPSP adalah untuk mengetahui perkembangan anak normal atau ada penyimpangan (Depkes RI, 2006).

\section{Pengolahan Data}

\section{Editing}

Langkah ini dilakukan untuk memeriksa data hasil dari observasi langsung, wawacara dan jawaban dari kuesioner yang diberikan. Serta meneliti kelengkapan, kejelasan, konsistensi dan kesinambungan data.

2. Koding

Memberi tanda atau simbol pada variabel penelitian untuk memudahkan peneliti.

3. Skoring

Memberikan skor atau nilai pada setiap jawaban yang diberikan oleh responden.

4. Entri

Entri merupakan kegiatan yang dilakukan untuk memasukan data-data kedalam program komputer.

5. Tabulating

Mengelompokan data sesuai dengan tujuan penelitian uji hubungan. Kemudian direkap dan disusun dalam bentuk tabel agar dapat dibaca dan mudah untuk dilakukan analisis lebih lanjut untuk pengambilan kesimpulan.

\section{Analisis Data}

Analisis data dilakukan secara deskriptif kuantitatif. Setelah melakukan pengambilan dan pengumpulan data kemudian data dengan kuesioner, maka dilakukan dianalisa menggunakan analisis univariat dan bivariat. Untuk melihat perbandingan variabel bebas dengan variabel terikat, dengan uji statistik Uji $\mathrm{T}$ Independen.

\section{Analisis Univariat}

Dilakukan untuk mendeskripsikan seluruh variabel baik variabel bebas maupun terikat. Analisis univariat digunakan untuk mendeskripsikan tiap-tiap variabel yaitu 
Pengaruh pemberian ASI Eksklusif terhadap tumbuh kembang bayi umur 6-24 bulan.

2. Analisis Bivariat

Analisis bivariat dilakukan terhadap semua variabel. Karena skala data pada penelitian ini berbentuk ordinal dan nominal maka menggunakan uji T Independen.

a. Jika $\mathrm{p}>0,05$ maka Ho diterima artinya tidak ada perbedaan yang signifikan antara variabel bebas dan variabel terikat.

b. Jika $\mathrm{p}<0,05$ maka Ha diterima yang artinya ada pengaruh yang signifikan antara variabel bebas dengan variabel terikat.

\section{HASIL DAN PEMBAHASAN}

Karakteristik Responden

1 Umur

Distribusi frekuensi responden menurut jenis kelamin bayi umur 6-24 bulan di nagari Sariak Laweh Kecamatan Akabiluru tahun 2018 dapat dilihat pada Tabel 1. Berdasarkan Tabel 1 dapat diketahui bahwa sebagian besar responden berumur 12 dan 24 bulan yaitu $20.0 \%$.

Tabel 1. Distribusi Responden Berdasarkan Umur Pada Bayi di Nagari Sariak Laweh Wilayah Kerja Puskesmas Batu Hampar Kecamatan Akabiluru Tahun 2018

\begin{tabular}{ccc}
\hline Umur & $\mathrm{f}$ & $\%$ \\
\hline 6 bulan & 4 & 13.3 \\
9 bulan & 4 & 13.3 \\
12 bulan & 6 & 20.0 \\
15 bulan & 5 & 16.7 \\
18 bulan & 4 & 13.3 \\
21 bulan & 1 & 3.3 \\
24 bulan & 6 & 20.0 \\
$\mathrm{~N}$ & 30 & 100.0 \\
\hline
\end{tabular}

Tabel 2. Distribusi Responden Berdasarkan Jenis Kelamin Pada Bayi di Nagari Sariak Laweh Wilayah Kerja Puskesmas Batu Hampar Kecamatan Akabiluru Tahun 2018

\begin{tabular}{ccc}
\hline Jenis Kelamin & f & $\%$ \\
\hline Laki-laki & 17 & 56.7 \\
Perempuan & 13 & 43.3 \\
$\mathrm{~N}$ & 30 & 100.0 \\
\hline
\end{tabular}

Tabel 3. Distribusi Responden Berdasarkan Berat Badan Pada Bayi di Nagari Sariak Laweh Wilayah Kerja Puskesmas Batu Hampar Kecamatan Akabiluru Tahun 2018

\begin{tabular}{ccc}
\hline Berat Badan & f & $\%$ \\
\hline $7.9-8.6 \mathrm{~kg}$ & 5 & 16.7 \\
$8.9-9.4 \mathrm{~kg}$ & 5 & 16.7 \\
$9.6-10.1 \mathrm{~kg}$ & 8 & 26.7 \\
$10.3-10.7 \mathrm{~kg}$ & 4 & 13.3 \\
$10.9-11.3 \mathrm{~kg}$ & 1 & 3.3 \\
$11.5-12.2 \mathrm{~kg}$ & 7 & 23.3 \\
$\mathrm{~N}$ & 30 & $100 \%$ \\
\hline
\end{tabular}




\section{Jenis Kelamin}

Distribusi frekuensi responden menurut jenis kelamin bayi 6-24 bln di nagari Sariak Laweh Kecamatan Akabiluru Tahun 2018 dapat dilihat pada Tabel 2. Berdasarkan Tabel 2 dapat diketahui bahwa sebagian besar responden berjenis kelamin laki-laki yaitu $56.7 \%$.

3. Berat badan

Distribusi frekuensi responden menurut berat badan bayi 6-24 bln di nagari Sariak Laweh Kecamatan Akabiluru tahun 2018 dapat dilihat pada Tabel 3. Berdasarkan Tabel 3 dapat diketahui bahwa sebagian besar responden mempunyai berat badan 9.6-10.7 $\mathrm{kg}$ yaitu $26.7 \%$.

4. Panjang badan

Distribusi frekuensi responden menurut panjang badan bayia 6-24 bln di nagari Sariak Laweh Kecamatan Akabiluru Tahun 2018 dapat dilihat pada Tabel 4. Berdasarkan Tabel 4 dapat diketahui bahwa sebagian besar responden mempunyai panjang badan 67.6-72 cm yaitu $26.7 \%$.

5. Lingkar Kepala

Berdasarkan Tabel 5 diatas dapat diketahui bahwa sebagian besar respnden mempunyai lingkar kepala dari rentang 43-50.5 cm yaitu $43.3 \%$.

\section{ASI Eksklusif}

Distribusi frekuensi responden menurut pemberian ASI Eksklusif pada bayi umur 6-24 bulan di Nagari Sariak Kecamatan Akabiluru Tahun 2018 dapat dilihat pada Tabel 6. Berdasarkan Tabel 6 dapat diketahui bahwa jumlah responden yang diberikan ASI Eksklusif sama dengan jumlah responden yang tidak diberikan ASI Eksklusif.

Tabel 4. Distribusi Responden Berdasarkan Panjang Badan Pada Bayi di Nagari Sariak Laweh Wilayah Kerja Puskesmas Batu Hampar Kecamatan Akabiluru Tahun 2018.

\begin{tabular}{ccc}
\hline Panjang Badan & F & $\%$ \\
\hline $67.6-72 \mathrm{~cm}$ & 8 & 26.7 \\
$73.3-75.7 \mathrm{~cm}$ & 6 & 20.0 \\
$76.9-79.1 \mathrm{~cm}$ & 5 & 16.7 \\
$80.2-83.2 \mathrm{~cm}$ & 4 & 13.3 \\
$84.2-87.8 \mathrm{~cm}$ & 7 & 23.3 \\
$\mathrm{~N}$ & 30 & 100 \\
\hline
\end{tabular}

Tabel.5. Distribusi Responden Berdasarkan Lingkar Kepala Pada Bayi di Nagari Sariak Laweh Wilayah Kerja Puskesmas Batu Hampar Kecamatan Akabiluru Tahun 2018

\begin{tabular}{ccc}
\hline Lingkar kepala & $\mathrm{f}$ & $\%$ \\
\hline $40-47.5 \mathrm{~cm}$ & 4 & 13.3 \\
$41.5-49 \mathrm{~cm}$ & 6 & 20.0 \\
$43-50.5 \mathrm{~cm}$ & 13 & 43.3 \\
$44.5-51.5 \mathrm{~cm}$ & 7 & 23.3 \\
$\mathrm{~N}$ & 30 & 100 \\
\hline
\end{tabular}

Tabel .6. Distribusi Frekuensi Responden Berdasarkan Pemberian ASI Eksklusif Pada Bayi di Nagari Sariak Laweh Wilayah Kerja Puskesmas Batu Hampar Kecamatan Akabiluru Tahun 2018

\begin{tabular}{ccc}
\hline ASI Eksklusif & F & $\%$ \\
\hline Diberikan & 15 & 50 \\
Tidak Diberikan & 15 & 50 \\
N & 30 & 100 \\
\hline
\end{tabular}


Mukhlis, H. 2019. Pengaruh Pemberian ASI Eksklusif terhadap Tumbuh Kembang Bayi Umur 6-24 Bulan di Nagari Sariak Laweh Kec. Akabiluru. Sainstek : Jurnal Sains dan Teknologi. 11 (1) : 37 - 45

Tabel.7. Gambaran Berat Badan Bayi berdasarkan Pemberian ASI Eksklusif di Nagari Sariak Laweh Wilayah Kerja Puskesmas Batu Hampar Kecamatan Akabiluru Tahun 2018

\begin{tabular}{ccc}
\hline ASI Eksklusif & Mean $(\mathrm{kg})$ & St.Dev \\
\hline Diberikan & 9.83 & 1,521 \\
Tidak Diberikan & 10.06 & 1,453 \\
\hline
\end{tabular}

Tabel 8. Gambaran Panjang Badan Bayi berdasarkan ASI Eksklusif di Nagari Sariak Laweh Wilayah Kerja Puskesmas Batu Hampar Kecamatan Akabiluru Tahun 2018

\begin{tabular}{ccc}
\hline ASI Ekslusif & Mean $(\mathrm{cm})$ & St.Dev \\
\hline Diberikan & 76,97 & 7,656 \\
Tidak Diberikan & 77,70 & 6,891 \\
\hline
\end{tabular}

Tabel 9. Gambaran Lingkar Kepala Bayi berdasarkan Pemberian ASI Eksklusif Di Nagari Sariak Laweh Wilayah Kerja Puskesmas Batu Hampar Kecamatan Akabiluru Tahun 2018

\begin{tabular}{ccc}
\hline ASI Eksklusif & Mean $(\mathrm{cm})$ & St.Dev \\
\hline Diberikan & 43,06 & 2,737 \\
Tidak Diberikan & 43,46 & 2,099 \\
\hline
\end{tabular}

Tabel 10. Berat Badan Bayi berdasarkan Pemberian ASI Eksklusif Di Nagari Sariak Laweh Wilayah Kerja Puskesmas Batu Hampar Kecamatan Akabiluru Tahun 2018

\begin{tabular}{|c|c|c|c|}
\hline \multirow{2}{*}{ ASI Eksklusif } & \multicolumn{2}{|c|}{ Berat Badan (gr) } & \multirow{2}{*}{ P. Value } \\
\hline & Mean $(\mathrm{kg})$ & St.Dev & \\
\hline Diberikan & 9.83 & 1,521 & 0,680 \\
\hline Tidak Diberikan & 10.06 & 1,453 & \\
\hline
\end{tabular}

1. Analisa Univariat

Tabel 7. menunjukkan bahwa rata-rata berat badan bayi yang diberikan ASI Ekslusif $9.83 \mathrm{~kg}$ dengan standar deviasi 1,521 sedangkan rata-rata berat badan bayi yang tidak diberikan ASI Eksklusif $10.06 \mathrm{~kg}$ dengan standar deviasi 1,453 . Tabel 8 menunjukkan bahwa rata-rata panjang badan bayi yang diberikan ASI Eksklusif 76,97 $\mathrm{cm}$ dengan standar deviasi 7,656 sedangkan rata-rata panjang badan bayi yang tidak diberikan 77,70 dengan standar deviasi 6,891. Tabel 9 menunujukkan bahwa rata-rata lingkar kepala bayi yang diberikan ASI Eksklusif 43,46 cm dengan standar deviasi 2,099 sedangkan ratarata lingkar kepala bayi yang tidak diberikan ASI Eksklusif 43,06 dengan standar deviasi 2,737 .

2. Analisis Bivariat
Dari Tabel 10 dapat dilihat bahwa ratarata pertumbuhan berat badan bayi yang diberikan ASI Eksklusif adalah $9.83 \mathrm{~kg}$ dengan standar deviasi 1,521 sedangkan rata-rata pertumbuhan berat badan bayi yang tidak diberikan ASI Eksklusif adalah $10.06 \mathrm{~kg}$ dengan standar deviasi 1,453 . Nilai $\mathrm{P}$ value didapatkan $\mathrm{P}=0,680>0,05$ artinya tidak ada pengaruh berat badan bayi yang diberikan ASI Eksklusif dengan bayi yang tidak diberikan ASI Eksklusif di Nagari Sariak Laweh. Pada penelitian ini, rata-rata pertumbuhan berat badan bayi usia 6-24 bulan yang diberikan ASI Eksklusif adalah $9.83 \mathrm{~kg}$ dengan standar deviasi 1,521, sedangkan rata-rata pertumbuhan berat badan bayi yang tidak diberikan ASI Eksklusif adalah $10.06 \mathrm{~kg}$ dengan standar deviasi 1,453. Rata - rata berat badan bayi mendapatkan ASI Eksklusif lebih ringan dibandingkan dengan 
rata - rata berat badan bayi yang tidak diberikan ASI Eksklusif.

Berdasarkan hasil uji $\mathrm{T}$ independen pada penelitian ini menunjukkan bahwa pemberian ASI ekslusif berpengaruh terhadap pertumbuhan pada bayi yang diberikan ASI Ekslusif dan yang tidak diberikan ASI Eksklusif tapi tidak signifikan dengan nilai $\mathrm{p}>$ 0,05 . Penelitian ini sebanding dengan penelitian yang dilakukan oleh Cahyadi (2012), yang menunjukkan bahwa hubungan pemberian ASI tidak signifikan dengan pertumbuhan bayi dengan nilai $\mathrm{p}=0,153(\mathrm{p}>0,05)$. Pertumbuhan antara berat badan dan tinggi badan ada hubungan yang linear jika pertumbuhan anak normal. Pemberian ASI saja juga dapat mempengaruhi peningkatan berat badan dan tinggi badan agar pertumbuhan seimbang.

Dari Tabel 11 dapat dilihat bahwa ratarata pertumbuhan panjang badan bayi yang diberikan ASI Eksklusif adalah 76,97 cm dengan standar deviasi 7,656 sedangkan rata- rata pertumbuhan panjang badan bayi yang tidak diberikan ASI Eksklusif adalah 77,70 dengan standar deviasi 6,891. Pada penelitian ini, rata-rata pertumbuhan panjang badanabayi usia 6-24 bulan yang diberikan ASI Eksklusif adalah 76,97 $\mathrm{cm}$ dengan standar deviasi 7,656, sedangkan rata-rata pertumbuhan panjang badan bayi usia 6-24 bulan yang tidak diberikan ASI Eksklusif adalah 77,70 cm dengan standar deviasi 6,891. Rata - rata panjang badan bayi yang diberikan ASI Eksklusif lebih pendek dibandingkan bayi yang tidak diberikan ASI Eksklusif. Hasil analisis statistik menunjukkan tidak terdapat perbedaan yang signifikan ratarata tumbuh kembang bayi usia 0-6 bulan yang mendapat ASI secara Eksklusif dengan bayi yang mendapat ASI Non eksklusif $(\mathrm{p}=0,144$ alpha=0,05). Menurut (Soetjiningsih, 2012) secara garis besar tumbuh kembangnya anak dipengaruhi dua faktor yaitu faktor genetik dan lingkungan.

Tabel 11. Panjang Badan Bayi berdasarkan Pemberian ASI Eksklusif Di Nagari Sariak Laweh Wilayah Kerja Puskesmas Batu Hampar Kecamatan Akabiluru Tahun 2018

\begin{tabular}{cccc}
\hline \multirow{2}{*}{ ASI Eksklusif } & \multicolumn{2}{c}{ Panjang Badan $(\mathrm{cm})$} & \multirow{2}{*}{ P. Value } \\
& Mean $(\mathrm{cm})$ & St.Dev & \\
\hline Diberikan & 76,97 & 7,656 & 0,786 \\
Tidak Diberikan & 77,70 & 6,891 & \\
\hline
\end{tabular}

Tabel 12. Lingkar Kepala Bayi berdasarkan Pemberian ASI Eksklusif Di Nagari Sariak Laweh Wilayah Kerja Puskesmas Batu Hampar Kecamatan Akabiluru Tahun 2018

\begin{tabular}{cccc}
\hline \multirow{2}{*}{ ASI Eksklusif } & \multicolumn{2}{c}{ Lingkar Kepala $(\mathrm{cm})$} & \multirow{2}{*}{ P. Value } \\
& Mean $(\mathrm{cm})$ & St.Dev & \multirow{2}{*}{. } \\
\hline Diberikan & 43,06 & 2,737 & 0,657 \\
Tidak Diberikan & 43,46 & 2,099 & \\
\hline
\end{tabular}

Tabel 13. Perkembangan bayi ASI Eksklusif berdasarkan KPSP di Nagari Sariak Laweh Wilayah Kerja Puskesmas Batu Hampar Kecamatan Akabiluru Tahun 2018

\begin{tabular}{|c|c|c|c|}
\hline \multirow{2}{*}{ KPSP } & \multicolumn{2}{|c|}{ ASI Eksklusif } & \multirow{2}{*}{ P. Value } \\
\hline & $\mathrm{f}$ & $\%$ & \\
\hline Sesuai & 29 & 96,7 & 0,326 \\
\hline Tidak sesuai & 1 & 3,3 & \\
\hline $\mathrm{N}$ & 30 & 100 & \\
\hline
\end{tabular}


Dari Tabel 12 dapat dilihat bahwa ratarata pertumbuhan lingkar kepala bayi yang diberikan ASI Eksklusif adalah 43,06 cm dengan standar deviasi 2,737 sedangkan ratarata pertumbuhan lingkar kepala bayi yang tidak diberikan ASI Eksklusif adalah 43,46 dengan standar deviasi 2,099. Nilai $P$ value didapatkan $\mathrm{P}=0,657>0,05$ artinya tidak ada pengaruh lingkar kepala bayi yang diberikan ASI Ekslusif dengan bayi yang tidak diberikan ASI Eksklusif di Nagari Sariak Laweh tahun 2018. Pada penelitian ini, rata-rata pertumbuhan lingkar kepala bayi usia 6-24 bulan yang diberikan ASI Eksklusif adalah 43,06 cm dengan standar deviasi 2,737, sedangkan ratarata pertumbuhan lingkar kepala bayi yang diberikan Susu Formula adalah 43,46 cm dengan standar deviasi 2,099. Rata -rata lingkar kepala bayi yang diberikan ASI Eksklusif lebih besar dibandingkan dengan rata-rata lingkar kepala bayi yang tidak diberikan ASI Eksklusif.

Pertumbuhan lingkar kepala bayi berjalan sangat cepat selama 6 bulan pertama, lingkar kepala bertambah setiap bulannya sekitar 1,5 $\mathrm{cm}$. Pertambahan ukuran kepala mencerminkan pertumbuhan dan diferensiasi sistem saraf (Wong, Eaton, Wilson, Winkelstein, \& Schwartz, 2008). Pertambahan yang relatif konstan juga dapat diketahui dari proporsi besar kepala dengan panjang badan. Hal ini juga sejalan dengan penelitian (Dewi, 2016), bahwa Bayi yang tidak diberikan ASI eksklusif memiliki pertumbuhan berdasarkan pengukuran lingkar kepala semua tidak normal sebanyak 3 responden $(11,11 \%)$. Bayi yang diberikan ASI eksklusif memiliki pertumbuhan berdasarkan pengukuran lingkar kepala semua normal sebanyak 16 responden $(59,25 \%)$. Hasil penelitian lain yang dilakukan oleh (Jaldin, Pinheiro, Santos, Muniz, \& Brito, 2011) menunjukkan hasil bahwa semua anak yang diberikan ASI Eksklusif memiliki lingkar kepala yang normal dan sedikit lebih besar dibandingkan dengan anak yang tidak diberikan ASI Eksklusif pada 6 bulan pertama bayi lahir. Menurut Asumsi peneliti, bahwa pengukuran lingkar kepala anak tidak begitu berpengaruh karena pada saat di lapangan, peneliti mendapati ukuran Lingkar kepala bayi ASI Eksklusif dan lingkar Kepala bayi yang tidak diberikan ASI Eksklusif tidak jauh berbeda.

Berdasarkan Tabel 13 dapat diketahui bahwa hasil dari kuisioner KPSP menunjukkan perkembangan Bayi ASI Eksklusif dan ASI Non Eksklusif terlihat baik, dengan rata-rata perkembangan yang sesuai $96.7 \%$. Nilai $P$ value didapatkan $\mathrm{P}=0,326>0,05$ artinya tidak ada pengaruh perkembangan bayi yang diberikan ASI Ekslusif dengan bayi yang tidak diberikan ASI Eksklusif di Nagari Sariak Laweh tahun 2018. Pada penelitian ini, didapatkan hasil 29 bayi $(96,7 \%)$ perkembangan bayiasesuai dengan umur bayi, dan 1 bayi $(3,3 \%)$ perkembangan bayi tidak sesuai dengan umur bayi. Dengan p value 0,326 $>0,05$ artinya tidak ada pengaruh perkembangan bayi yang diberikan ASI Eksklusif dengan bayi yang tidak diberikan ASI Eksklusif.

Hasil penelitian sama dilakukan di Puskesmas Dersalam Kabupaten Kudus oleh Sari tahun 2011, dengan hasil nilai $\mathrm{p}$ value $=$ 0,053 bahwa tidak ada hubungan yang signifikan antara pemberian ASI Eksklusif dengan perkembangan motorik anak. Dari data yang didapatkan, ada 1 bayi yang tidak diberikan ASI Eksklusif mempunyai perkembangan yang tidak sesuai dengan umur bayi. Ini menyebabkan keterlambatan perkembangan pada bayi. Hal ini terjadi karena kandungan ASI mempunyai banyak manfaat diantaranya meningkatkan daya tahan tubuh, nutrisi yang baik, meningkatkan jalinan kasih sayang antara ibu dan bayi. Oleh karena itu jika bayi tidak mendapatkan perlindungan dan nutrisi yang baik untuk tubuhnya maka salah satu dampaknya adalah keterlambatan perkembangan bayi.

\section{KESIMPULAN}

Berdasarkan hasil penelitian yang telah dilakukan pada bayi umur 6-24 bulan di Nagari Sariak Laweh Wilayah Kerja Puskesmas Batu 
Hampar, Kecamatan Akabiluru tahun 2018 dapat disimpulkan sebagai berikut :

Pertumbuhan dan perkembangan bayi yang diberikan ASI Eksklusif berbeda dengan pertumbuhan dan perkembangan bayi yang tidak diberikan ASI Eksklusif. Dengan jumlah sampel 30 bayi, maka didapatkan bayi yang diberikan ASI Eksklusif 15 bayi (50\%) dan bayi yang tidak diberikan ASI Eksklusif 15 bayi (50\%). Dengan pemberian ASI Eksklusif pada bayi didapatkan rata-rata berat badan bayi $(9,83$ $\mathrm{kg}$ ), sedangkan rata-rata berat badan bayi yang tidak diberikan ASI Eksklusif (10.06 kg). Dari hasil uji didapatkan $\mathrm{p}(0,680)>0,05$ dapat disimpulkan bahwa tidak ada pengaruh pemberian ASI Eksklusif terhadap berat badan bayi. Dengan pemberian ASI Eksklusif pada bayi didapatkan rata-rata panjang badan bayi $(76,97 \mathrm{~cm})$, sedangkan rata-rata panjang badan bayi yang tidak diberikan ASI Eksklusif (77,70 $\mathrm{cm})$. Dari hasil uji didapatkan p $(0,786)>0,05$ dapat disimpulkan bahwa tidak ada pengaruh pemberian ASI Eksklusif terhadap panjang badan bayi. Dengan pemberian ASI Eksklusif pada bayi didapatkan rata-rata lingkar kepala bayi $(43,06 \mathrm{~cm})$, sedangkan rata-rata lingkar kepala bayi yang tidak diberikan ASI Eksklusif $(43,46 \mathrm{~cm})$. Dari hasil uji didapatkan $\mathrm{p}(0,657)$ $>0,05$ dapat disimpulkan bahwa tidak ada pengaruh pemberian ASI Eksklusif terhadap lingkar kepala bayi.

Dari kuisioner yang diberikan didapatkan hasil bahwa $(96,7 \%)$ perkembangan bayi sesuai dengan umur bayi, dan $(3,3 \%)$ perkembangan bayi tidak sesuai dengan umur bayi. Dari hasil uji didapatkan $\mathrm{p}$ value $(0,326)>0,05$ dapat disimpulkan bahwa tidak ada pengaruh ASI Eksklusif terhadap perkembangan bayi.

\section{DAFTAR KEPUSTAKAAN}

Depkes RI. (2006). Defenisi KPSP (Kuisioner Praskrining Perkembangan). Jakarta.

Dewi, F. K. (2016). Efektifitas Pemberian Asi Ekslusif terhadap Pertumbuhan dan Perkembangan Bayi di Posyandu Mawar Kecamatan Mersi Tahun 2015. Jurnal Ilmiah Kebidanan, 7(1), 1-13.

Jaldin, M., Pinheiro, F. S., Santos, A. M. dos, Muniz, N. C., \& Brito, L. M. O. (2011). Head circumference growth of exclusively breastfed infants during the first six months of life. Rev Paul Pediatr, 29(4), 509-914.

Posyandu. (2017). Populasi bayi 6-24 bulan di Nagari Sariak Laweh Sariak Laweh Kecamatan Akabiluru.

Sanjaya, W. (2011). Perencanaan dan Desain Sistem Pembelajaran. Jakarta: Kencana.

Soetjiningsih. (2012). Perkembangan Anak dan Permasalahannya dalam Buku Ajar I Ilmu Perkembangan Anak Dan Remaja. Jakarta: Sagung seto.

Sugiyono. (2011). Metode Penelitian Kuantitatif Kualitatif dan $R \& D$. Bandung: Alfabeta.

Wong, D. L., Eaton, H. M., Wilson, D., Winkelstein, M. L., \& Schwartz, P. (2008). Wong buku ajar keperawatan pediatrik. Jakarta: EGC. 